\title{
PENGARUH PEMBERIAN DOSIS BOKASIH KULIT BUAH KAKAO TERHADAP PERTUMBUHAN DAN HASIL TANAMAN CABAI
}

(Capsicum annuum L.)

\author{
Julianus Jeksen \\ Julianus_jeksen@yahoo.com \\ Program Studi Agroekoteknologi, Fakultas Pertanian Universitas Flores, Ende
}

\begin{abstract}
ABSTRAK
This research aims to know the effect of dosing cacao rind bokashi fertilizer to the growth and the increase of chili plants yield and also to know the optimum dose of bokashi which can provide the optimum growth and yield. The design used in this experiment is Randomized Block Design (RBD). The treatment used are P0 (without cacao rind fertilizer), P1 (cacao rind fertilizer 10 tons ha ${ }^{-1}=5.6 \mathrm{~kg} / \mathrm{ptk}$ ), P2 (cacao rind fertilizer 20 tons $\mathrm{ha}^{-1}=11.2 \mathrm{~kg} / \mathrm{ptk}$ ), P3 (cacao rind fertilizer 30 tons ha ${ }^{-1}=16.8 \mathrm{~kg} / \mathrm{ptk}$ ), P4 (cacao rind fertilizer 40 tons $\mathrm{ha}^{-} 1=22.4 \mathrm{~kg} / \mathrm{ptk}$ ). The variable of the observation in this research are the height of the plants, the number of leaves, the leaf width, the fruit weight $\tan ^{-1}$, the fruit weight $\mathrm{ha}^{-1}$. The result of this research indicates that the dosing of cacao rind bokashi fertilizer can influence the plants height with the total average of $24.52 \%$, the average number of leaves with a total of $14.56 \%$, and the average leaf width with a total of $29.55 \%$, and the total of fruits $\tan ^{-1} 31,46 \%$, the fruit weight $\tan ^{-1} 29.17 \%$, the fruit weight $\mathrm{ha}^{-1}$ $28.67 \%$. The optimum dose of cocoa rind bokashi 40 tons $\mathrm{ha}^{-1}$ can promote the optimum growth and yield of chili plants.
\end{abstract}

Keywords: cacao rind bokashi, chili plants.

\section{Latar Belakang}

Kebutuhan akan cabai semakin meningkat setiap tahun sejalan dengan pertumbuhan penduduk, jadi tidaklah mengherankan kalau cabai menjadi komoditas buah unggulan yang bernilai ekonomis tinggi. Permintaan cabai yang relatif tinggi hampir setiap harinya untuk bumbu masakan, industri makanan dan obat -obatan tidak pernah absen karena cabai merupakan bahan pangan yang memang dikonsumsi setiap saat. Hal 
Julianus: Pengaruh pemberian dosis bokasih kulit buah kakao terhadap pertumbuhan dan hasil tanaman cabai.

inilah yang kiranya membuat tanaman cabai amat populer dan terus dibudidayakan.

Seiring kebutuhan cabai yang terus meningkat, tidak dipungkiri harga cabai pun semakin lama semakin meningkat, ini berarti keuntungan yang didapat pun tak sedikit. Berdasarkan hal tersebut membuat banyak orang mencoba melirik usaha agribisnis ini. Namun dibalik keuntungannya yang menggiurkan terdapat juga kerugian yang tak sedikit.

Sunaryono (1984) mengemukakan bahwa produktifitas tanaman cabai keriting persatuan luas dapat mencapai rata - rata 20 - 30 ton/ha. Data statistik propinsi NTT tahun 2009 hasil panen cabai merah per hektar sebesar $10 \quad-15$ ton/ha, jauh lebih rendah jika dibandingkan dengan data di atas (BPS NTT, 2010). Data dari Dinas Pertanian dan Peternakan Kabupaten Ende total luas lahan yang dapat ditanami cabai adalah 11,2 ha sedangkan luas lahan yang dipanen hanya 9,5 ha dengan total produksi mencapai 66,7 ton dan memiliki produktifitas 7 ton/ha. Dalam berbudidaya, diperlukan perencanaan dan penguasaan teknologi agar kualitas tanaman benar - benar sesuai dengan yang diharapkan.

Salah satu faktor yang harus diperhatikan dalam berbudidaya adalah tersedianya unsur hara di dalam tanah, baik unsur hara makro maupun unsur hara mikro. Kebutuhan tanaman akan unsur hara dapat dipenuhi dengan cara pemupukan. Pemupukan bertujuan untuk memperbaiki kesuburan tanah sehingga pertumbuhan tanaman akan lebih baik. Pupuk yang biasa digunakan dalam bercocok tanam adalah pupuk organik dan pupuk anorganik.

Pupuk organik merupakan salah satu pupuk yang diberikan pada tanaman baik sebagai pupuk dasar maupun pupuk susulan. Pupuk organik ini banyak macamnya antara lain pupuk kandang, pupuk kompos dan pupuk bokasih. Pupuk bokasih ini merupakan pupuk organik yang mudah dibuat dan cepat digunakan untuk pemupukan.

Bahan yang dibutuhkan untuk membuat pupuk bokasih berasal dari limbah-limbah pertanian, antara lain seresah (daun-daunan), rumput dan kotoran ternak. Salah satu limbah pertanian yang baru sedikit dimanfaatkan 
Julianus: Pengaruh pemberian dosis bokasih kulit buah kakao terhadap pertumbuhan dan hasil tanaman cabai.

adalah limbah dari perkebunan kakao yaitu kulit buah kakao.

Data statistik Propinsi NTT tahun 2011, mencatat luas areal perkebunan kakao di NTT sebesar 41.277,43 ha dan produksi pertahun mencapai $14.277,70$ ton. Khusus untuk Kabupaten Ende luas areal perkebunan kakao adalah 5.800 ha, sedangkan produksi pertahunnya sebanyak 3.273 ton. Bila dilihat dari banyaknya produksi tersebut maka terdapat limbah kulit buah kakao yang berpotensi mencemari lingkungan. Menghindari terjadinya hal tersebut, dengan teknologi yang tepat limbah dari kulit buah kakao dapat dimanfaatkan sebagai sumber unsur hara tanaman dalam bentuk kompos dan bokasih.

Sebagai bahan organik kulit buah kakao mempunyai komposisi hara dan senyawa yang sangat potensial sebagai medium tumbuh tanaman. Kadar air untuk kakao lindak sekitar 86\% dan kadar bahan organiknya sekitar 55,7\% (Soedarsono, 1997). Menurut Didiek dan Yufnal (2004) bokasih kulit buah kakao mempunyai $\mathrm{N}$ total 1,3\%, C-organik $33,71 \%$, P2O5 0,186\%, K2O 5,5\%, $\mathrm{CaO} 0,23 \%$ dan $\mathrm{MgO}$ 0,59\%. Pemupukan harus memperhatikan dosisnya, bila terlalu sedikit dan juga terlalu banyak dapat menghambat pertumbuhan tanaman sehingga tidak bisa menghasilkan produksi buah cabai yang baik. Hasil penelitian Soverda (2008) menyatakan pemberian bokasih kulit buah kakao dengan dosis 20 ton/ha memberikan pengaruh terbaik pada pertumbuhan dan hasil dari tanaman tomat. Tinggi tanaman tomat pada umur 44 hst yaitu $52,30 \mathrm{~cm}$ dan waktu muncul bunga terlihat pada umur 35 hst, sedangkan jumlah buah pertanaman mencapai 21 buah dengan bobot buah pertanaman $627 \mathrm{gr}$.

\section{METODE PENELITIAN}

\section{Tempat dan Waktu}

Penelitian dilaksanakan di Balai Penyuluh Pertanian (BPP) Ria Raja Kecamatan Ende Kabupaten Ende. Pelaksanaan penelitian mulai dari bulan Juni sampai dengan bulan September 2013.

\section{Bahan dan Alat}

Bahan-bahan yang digunakan dalam percobaan ini adalah benih cabai varietas hibrida Chia Tai Seed, bokasih kulit buah kakao. Sedangkan Alat-alat yang digunakan adalah pacul, sabit, ajir, ember plastik, sekop, timbangan, oven, meteran, 
Julianus: Pengaruh pemberian dosis bokasih kulit buah kakao terhadap pertumbuhan dan hasil tanaman cabai.

penggaris, tali rafia, kantong plastik, alat tulis, dan kamera.

\section{Rancangan Penelitian}

Rancangan yang digunakan dalam percobaan ini adalah Rancangan Acak Kelompok (RAK) dengan pola faktor tunggal yang terdiri dari lima perlakuan yaitu :

P0: Tanpa pemberian bokasih kulit buah kakao

P1: Pemberian bokasih kulit buah kakao dengan dosis 10 ton/ha

P2: Pemberian bokasih kulit buah kakao dengan dosis 20 ton/ha

P3: Pemberian bokasih kulit buah kakao dengan dosis 30 ton/ha

P4: Pemberian bokasih kulit buah kakao dengan dosis 40 ton/ha.

Semua perlakuan diulang sebanyak empat kali sehingga terdapat 20 petak percobaan.

\section{Variabel Pengamatan}

Variabel pengamatan dalam penelitian ini adalah Tinggi Tanaman (Cm), Jumlah Daun, Luas Daun Pertanaman, Jumlah Buah $\operatorname{Tan}^{-1}$, Berat Buah Segar Per Tanaman (Kg) dan Berat Buah Segar Per Hektar (Ton).

\section{Hasil dan Pembahasan}

Variabel pertumbuhan
Hasil analisis sidik ragam menunjukkan bahwa perlakuan bokasih kulit buah kakao yang berbeda memberikan pengaruh yang sangat nyata terhadap tinggi tanaman, jumlah daun, dan luas daun pada setiap umur pengamatan Hasil analisis stastik menunjukan bahwa pengaruh pemberian dosis pupuk bokasih kulit buah kakao yang berbeda memberikan pengaruh yang sangat nyata terhadap variabel tinggi tanaman, jumlah daun dan luas daun dengan rataan total tinggi tanaman dan jumlah daun. Dosis 0 ton ha ${ }^{-1}$ ke 10 ton $\mathrm{ha}^{-1}$ meningkatkan rataan total tinggi tanaman, jumlah daun dan luas daun sebesar 2,30\%, 6,00\%, 3,89\%; 10 ton $\mathrm{ha}^{-1}$ ke 20 ton ha ${ }^{-1}$ sebesar 6,94\%, 14,62 $\%, 14,62 \%$; 20 ton ha ${ }^{-1}$ ke 30 ton $\mathrm{ha}^{-1}$ sebesar 21,00\%,23,25\%, 17,100\%; 30 ton ha ${ }^{-1}$ ke 40 ton ha ${ }^{-1}$ sebesar $24,52 \%$, $29,55 \%, 14,56 \%$.

Peningkatan tinggi tanaman, jumlah daun, dan luas daun menunjukkan bahwa hipotesis yang pertama (1) diterima dan hipotesis kedua (2) di tolak karena semakin tinggi peningkatan dosis pupuk bokasih kulit buah kakao pada perlakuan 40 ton ha $^{-1}$ (P4) maka semakin banyak kandungan unsur hara yang akan diserap 
Julianus: Pengaruh pemberian dosis bokasih kulit buah kakao terhadap pertumbuhan dan hasil tanaman cabai.

oleh tanaman. Hal tersebut disebabkan karena kandungan hara mineral buah kakao cukup tinggi, khususnya hara Kalium dan Nitrogen. $61 \%$ dari total nutrien buah kakao disimpan di dalam kulit buah. Bokasih kulit buah kakao mempunyai $\mathrm{N}$ total $1,3 \%, \mathrm{C}-$ organik $33,71 \%, \mathrm{P}_{2} \mathrm{O}_{5} 0,186 \%, \mathrm{~K}_{2} \mathrm{O} 5,5 \%, \mathrm{CaO}$ 0,23\% dan $\mathrm{MgO}$ 0,59\% (Didiek dan Yufnal, 2004).

Kandungan unsur hara Nitrogen pada tanaman mempunyai pengaruh untuk merangsang pertumbuhan tanaman dengan cepat serta menyebabkan daun dan batang berwarna hijau karena unsur $\mathrm{N}$ merupakan bahan pembentuk klorofil. Unsur hara $\mathrm{N}$ dibutuhkan dalam jumlah relatif besar pada setiap tahap pertumbuhan tanaman, khususnya pada tahap pertumbuhan vegetatif seperti pembentukan tunas, perkembangan batang dan daun.

Daun tanaman merupakan salah satu organ tumbuhan yang tumbuh dari batang dan umumnya berwarna hijau (mengandung klorofil) yang berfungsi sebagai penerima cahaya matahari melalui fotosintesis yang menghasilkan karbohidrat, pati dan gula untuk keperluan pertumbuhan dan perkembangan tanaman. Peningkatan luas daun pada tanaman akan mempengaruhi penyerapan energi cahaya matahari, semakin luas daun tanaman kemampuan menyerap cahaya akan semakin banyak sehingga proses fotosintesis dalam tubuh tanaman akan semakin meningkat (Anonimus, 2010). Meningkatnya hasil fotosintesis pada tanaman maka pertumbuhan tanaman akan meningkat (Krisnawati, 2008).

Tanaman cabai tanpa pemupukan kontrol (P0) memberikan pengaruh yang lebih rendah dibandingkan dengan tanaman lain yang diaplikasikan pupuk bokasih kulit buah kakao. Hal tersebut disebabkan karena kandungan unsur hara dalam tanah tidak dapat mencukupi pertumbuhan vegetatif tanaman cabai yang optimal.

\section{Variabel Hasil}

Hasil analisis sidik ragam menunjukkan bahwa dosis pupuk bokasih kulit buah kakao berpengaruh sangat nyata terhadap semua komponen hasil tanaman cabai. Perlakuan dosis pupuk bokasih kulit buah kakao 40 ton $\mathrm{ha}^{-1}$ (P4) memberikan nilai yang paling tinggi dibanding perlakuan lainnya. Dosis 0 ton ha ${ }^{-1}$ ke 10 ton $\mathrm{ha}^{-1}$ 
Julianus: Pengaruh pemberian dosis bokasih kulit buah kakao terhadap pertumbuhan dan hasil tanaman cabai.

meningkatkan rataan total jumlah buah, berat buah pertanaman dan berat buah perhektar sebesar 3,01\%, 5,56\%, 2,76 $\%$; 10 ton ha ${ }^{-1}$ ke 20 ton ha ${ }^{-1}$ sebesar $32,80 \%, 23,53 \%, 31,76 \% ; 20$ ton $\mathrm{ha}^{-1}$ ke 30 ton ha ${ }^{-1}$ sebesar $29,01 \%, 23,53 \%$, 24,03\%; 30 ton ha ${ }^{-1}$ ke 40 ton ha $^{-1}$ sebesar $31,46 \%, 29,17 \%, 28,67 \%$. Perlakuan pemberian pupuk bokasih kulit buah kakao sebanyak 40 ton $\mathrm{ha}^{-1}$ (P4) menunjukan peningkatan nilai Jumlah Buah $\operatorname{Tan}^{-1}$, Berat Buah $\operatorname{Tan}^{-1}$, Berat Buah $\mathrm{Ha}^{-1}$, yang paling tinggi dibanding perlakuan lainnya (P0, P1, P2 dan P3). Hal ini disebabkan karena keadaan tanah di lokasi penelitian tergolong miskin hara.

Peningkatan jumlah buah pertanaman, berat buah pertanaman dan berat buah perhektar menunjukan bahwa unsur hara yang terdapat dalam pupuk bokasih kulit buah kakao yang diaplikasikan pada tanaman cabai berpengaruh terhadap banyaknya buah cabai. Bokasih kulit buah kakao mengandung unsur hara makro seperti $\mathrm{N}$, $\mathrm{P}, \mathrm{K}, \mathrm{Ca}, \mathrm{Mg}, \mathrm{S}$ dan juga mengandung unsur hara mikro antara lain $\mathrm{Mn}, \mathrm{Zn}, \mathrm{Fe}$, $\mathrm{S}, \mathrm{B}, \mathrm{Ca}$ dan $\mathrm{Mg}$ yang berperan penting sebagai katalisator dalam proses sintesis protein dan pembentukan klorofil dalam proses fotosintesis. Hasil fotosintesis yang berupa karbohidrat selain disuplai ke batang, daun dan akar juga disuplai untuk perkembangan generatif tanaman dan tersimpan sebagai cadangan makanan (Harjadi, 2000).

Sudjijo (1992), menyatakan bahwa unsur hara Phosfat berperan penting untuk merangsang pembentukan bunga, buah dan biji serta dapat merangsang pemasakan buah. Unsur hara Kalium berperan dalam metabolisme air dalam tanaman, absorpsi hara, respirasi, transpirasi, translokasi karbohidrat, membentuk batang yang lebih kuat dan sangat berpengaruh terhadap hasil tanaman baik kualitas maupun kuantitasnya.

Pemberian pupuk organik dapat meningkatkan kandungan $\mathrm{C}$ organik. Kandungan $\mathrm{C}$ organik berpengaruh pada pembentukan buah dan umbi. Menurut Sudjijo(1992), kandungan C organik akan mempengaruhi terbentuknya seratserat yang lebih besar pada buah dan umbi sehingga mempengaruhi kekerasan pada buah dan umbi yang akhirnya sangat berpengaruh terhadap hasil tanaman. Sarief (1989), menyatakan 
Julianus: Pengaruh pemberian dosis bokasih kulit buah kakao terhadap pertumbuhan dan hasil tanaman cabai.

bahwa dengan tersedianya unsur hara dalam jumlah memadai maka proses fisiologis di dalam tubuh tanaman akan berjalan baik, terutama unsur hara yang berperan dominan dalam pertumbuhan dan perkembangan tanaman.

\section{Kesimpulan}

1. Peningkatan dosis pupuk bokasi kulit buah kakao berpengaruh sangat nyata dengan rataan total tinggi tanaman sebesar 24,52 \%, jumlah daun pertanaman sebesar $14,56 \%$, dan luas daun pertanaman sebesar 29.55 $\%$, dan jumlah buah $\tan ^{-1} 31,46 \%$, berat buah $\tan ^{-1} 29,17 \%$, berat buah $\mathrm{ha}^{-1} 28,67 \%$

2. Dosis optimum pupuk bokasi kulit buah kakao 40 ton ha- ${ }^{1}$ berpengaruh sangat nyata terhadap tinggi tanaman ( 58,50 cm), jumlah daun $(68,13)$, luas daun $(109,09 \mathrm{~cm})$, jumlah buah pertanaman $(95,56)$, berat buah pertanaman $(0,48 \mathrm{~kg})$ dan berat buah perhektar (13,71 ton).

\section{Ucapan Terima Kasih}

Pada kesempatan ini penulis ingin mengucapkan terima kasih kepada semua pihak yang telah membantu dengan caranya masing-masing dalam melengkapi tulisan ini.

\section{DAFTAR PUSTAKA}

Anonimous. 2011. Peranan Unsur Hara Dalam Meningkatkan Kesuburan Tanah dan Tanaman. http://organisasi.org/teknik-caramembuat-tanah-tetap-subur. Disidir tanggal 12 Nopember 2012.

Anonimous. 2005. Komponen Nutrisi yang Terkandung dalam Pupuk Bokasih. Kanisius, Yogyakarta.

Arafa. 2009. Pengelolaan Limbah Menjadi Pupuk Organik. http://susel.litbang.deptan.go.id/ind ex.php?option:com. Januari 2011

Bucman N dan Brady. 1982. Ilmu Tanah. Alih Bahasa Soegiman. Karya Aksara, Jakarta.

Tosin., D. dan N. Ratna Sari. 2010. Sukses Usaha dan Budidaya Cabai. Penerbit Atma Media Press, Yogyakarta.

Didiek H.G dan Yufnal Away. 2004. Orgadek, Aktivator Pengomposan. Pengembangan Hasil Penelitian Unit Penelitian Bioteknologi Perkebunan, Bogor.

Effi Ismawati Musnawar. 2003. Pembuatan dan Aplikasi Pupuk Organik Padat. Penebar Swadaya , Jakarta.

Hety,Y. 2003. Membuat Kompos Secara Kilat. Penebar Swadaya. Jakarta.

Harjadi. 2000. Peran Pupuk Oraganik Potensi Pupuk Organik di Indonesia - Kotoran Ternak - Kebutuhan Pupuk Organik. 
Julianus: Pengaruh pemberian dosis bokasih kulit buah kakao terhadap pertumbuhan dan hasil tanaman cabai.

http://unila.ac.id/wasetawan/files/20 10/10/fungsi-daun.pdf. Disidair tanggal 11 Juni 2012.

Krisnawati. 2008. Proses Fotosintesis Pada Daun dan Pemanfaatannya BagiTanaman.http://proxy.caw2.co m.indeks.php?vit=uggc $\% 3 \mathrm{~A} \% 2 \mathrm{~F}$ - xrgfrqvnna-p.-betnavxa $\% 2 \mathrm{~F}$.

Disidir tanggal 09 september 2012.

Purwono dan Tim Lentera. 2003. Bertanam Cabai Rawit dalam Pot. Agromedia Pustaka, Bogor.

Rohyanti. 2011. Pengaruh Pemberian Bokasih Jerami Padi terhadap Pertumbuhan Vegetatif Tanaman Tomat. http://poltalgaruda.org/download_ar tide.

Rahman Sutanto. 2002. Pertanian Organik. Kanisius, Yogyakarta.

Rukmana. 1999. Budidaya Cabai Hibrida sistem Mulsa Plastik. Kanisius, Yogyakarta.

Sarief. 1989. Peranan Unsur Hara Dalam Meningkatkan Kesuburan Tanah dan Tanaman. Badan Penelitian dan Pengembangan Pertanian Departemen Pertanian.

Soedarsono. 1997. Penebaran Kulit Buah Kakao Sebagai Sumber Bahan Organik dan Pengaruhnya terhadap Produksi Kakao. http://pustaka.unpad.ac.id/wp.conte nt/uploads/2009/04/pdf.

Sunaryono,H. 1984. Budidaya Cabai Merah. Penerbit Sinar Baru. Bandung
Simamora, S., dan Salundik. 2006. Meningkatkan Kualitas Kompos. PT. Agro Media Pustaka, Jakarta.

Sudjijo. 1992. Pengaruh Beberapa Jenis Pupuk Organik Terhadap pertumbuhan dan Hasil Tanaman Sayuran. Jurnal Hortikultura Balai penelitian Hortikultara Brastagi.

Soverda., N. 2008. Pengaruh Beberapa Macam Bokasih terhadap Pertumbuhan dan Hasil Tanaman Tomat. http://on-linejournal.unja.ac.id.

Winarso, S. 2005. Kesuburan Tanah. Gava Media. Yogyakarta. 